IRA-International Journal of Technology \& Engineering

ISSN 2455-4480; Vol.05, Issue 02 (2016)

Pg. no. 32-44

Institute of Research Advances

http://research-advances.org/index.php/IRAJTE

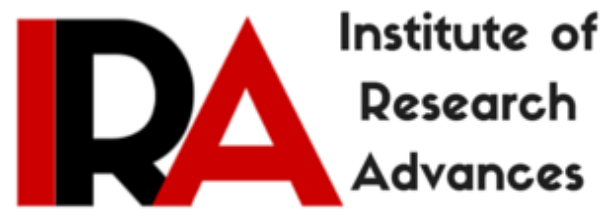

\title{
Developing an Appropriate Performance Measurement Framework for Total Quality Management (TQM) in Construction and Other Industries
}

\author{
Behnam Neyestani ${ }^{1}$ \& Joseph Berlin P. Juanzon ${ }^{2}$ \\ ${ }^{1}$ Ph.D. Candidate, Department of Civil Engineering, \\ De La Salle University, Manila, Philippines. \\ 2 Assist. Professor, Department of Civil Engineering, \\ De La Salle University, Manila, Philippines.
}

Type of Reviewed: Peer Reviewed.

DOI: http://dx.doi.org/10.21013/jte.v5.n2.p2

\section{How to cite this paper:}

Neyestani, B., \& Juanzon, J. (2016). Developing an Appropriate Performance Measurement Framework for Total Quality Management (TQM) in Construction and Other Industries. IRAInternational Journal of Technology \& Engineering (ISSN 2455-4480), 5(2), 32-44. doi:http://dx.doi.org/10.21013/jte.v5.n2.p2

(C) Institute of Research Advances

(c)) BY-NC

This work is licensed under a Creative Commons Attribution-Non Commercial 4.0 International License subject to proper citation to the publication source of the work.

Disclaimer: The scholarly papers as reviewed and published by the Institute of Research Advances (IRA) are the views and opinions of their respective authors and are not the views or opinions of the IRA. The IRA disclaims of any harm or loss caused due to the published content to any party. 


\begin{abstract}
Total quality management (TQM) is a set of opinions and ideas that widely called "management philosophy". This management technique is able to assist the construction firms in improving continuously the organization's performance, in order to satisfy customers and survive in the market. The success of TQM implementation is tightly dependent on identifying and selecting the appropriate critical success factors (CSFs), quality tools, and performance measures (KPIs) within TQM framework. Doubtlessly, a set of suitable performance measures (indicators) has a significant role to verify and ensure that TQM implementation can successfully achieve its aims in the organization. Thus, the main purpose of this paper was to develop a suitable framework to assess the effects of TQM implementation on organization's performance in construction industry. For this aim, the study was conducted a comprehensive literature review to specify the existing key performance indicators (KPIs) from 26 TQM frameworks that formulated by scholars. In data analysis, the only $20 \mathrm{KPIs}$ were found of $26 \mathrm{TQM}$ studies. The extracted KPIs (20) classified based on four dimensions of balanced scorecard (BSC), and then arranged from highest to lowest frequency for each perspective of BSC. Finally, a total of ten KPIs were determined and presented within BSC system as an appropriate performance measures framework, which enables evaluating critical areas that very vital to the success of TQM implementation in construction firms at project and enterprise levels.
\end{abstract}

Keywords: Total Quality Management (TQM); Performance Measurement Framework; Performance Measurement System (PMS); Key Performance Indicators (KPIs), and; Balanced Scored (BSC).

\title{
Introduction
}

The majority of the construction companies face many challenges and problems, such as "workmanship defects", delay, and "cost overrun in complementing their projects in all over the world. Since over the past three decades, the globalization and competition have been increasing. The competitive pressure forces construction firms to change their traditional methods in projects management with the aim of achieving the organizational goals successfully. This aim can be happened through the effective implementation of a "total quality management (TQM) system" (Harrington et al., 2012). TQM was first emerged by the contribution of quality gurus, such as Deming, Juran in Japan after Second World War. Later, Crosby, Feigenbaun, Ishikawa, and others, had significant role to develop this quality management approach. In 1990s, TQM has been introduced into the construction industry across many countries as "an improvement strategy". This management tool can continuously improve quality performance in different aspects of the organizations through its powerful methodology, best known (PDCA) Plan, Do, Check, and Act) cycle, but there are numerous obstacles to implement TQM effectively in the construction companies (Tang, et al., 2009). Several studies found the importance of the design and development of a proper performance measurement system (PMS) in successful TQM implementation within construction firms (Lee et al., 2011). The performance measurement system (PMS) as a management tool can be able to assist TQM implementation for "continuous improvements" and achieve "performance excellence" in the organizations (Takim and Akintoye, 2002). Without doubt, an appropriate performance measurement framework enables to change the entire organization, it presents a set of key performance indicators (KPIs) to the firms that should be considered to ensure successful implementation of TQM by detecting the gap between planned and achieved objectives (Oakland, 2003).

In fact, the majority of managers do not have enough knowledge concerning a systematic performance indicators, and employ just financial indicators to assess their organizational performance. However, traditional performance indicators, based on cost accounting information, provide little to support firms, and do not cover these intangible assets on the "quality journey". It is one of the most important reasons that the construction companies fail in TQM implementation at project and enterprise levels. Because the 
PMS is not just a set of performance indicators, it is indeed a strategic management tool, which can direct the management of construction organizations to identify their main goals, provide proper ways to achieve them, and ensure to approach these aims during TQM implementation. Furthermore, the use of the improper KPIs cannot indicate the condition of critical areas promoting business value within an organization. Therefore, it is vital for practitioners and scholars to formulate a proper data collection system (systematic performance indicators) through reviewing previous TQM studies that developed the PMSs within their TQM models for measuring the performance of TQM system (Kalpande et al., 2012; Oakland, 2003). Importantly, it was revealed of reviewing literature that the construction firms have been often employed the inappropriate PMSs that cannot enable to manage the organization through balancing the financial and non-financial measures. Meanwhile, Pimentel and Major (2014) criticized many studies on TQM and quality management programs that built their performance measurement frameworks by adopting wrong key performance indicators (KPIs), and there is a gap in the literature regarding this matter. Thus, this paper used a systematic review to determine the existing KPIs from previous empirical studies on TQM implementation in all over the world. After identifying the derived KPIs from literature review, the most frequently used KPIs were selected based on four dimensions of balanced scored (BSC), in order to assess the critical parts of the organizations during TQM implementation in the construction companies.

\section{Literature Review}

The performance is the output or the results of company's work, and getting every thing, which are related to organizational plans and goals (Mehmood et al., 2014). According to Omachonu and Ross (2004), there is an old maxim in management that says, "If you can't measure it, you cannot manage it". The concept of performance is "broader". The staffs in different industries are involved with performance like strategic planning, operations, finance, legal, and others in the organizations. Its multiple dimensions can be classified to "financial performance", and "non-financial performance" (Burli et al., 2012). In the late 1980s, researchers found that financial performance measures did not capture customer quality and the innovation demands of the changing environment (Pimentel and Major, 2014). The cost-accounting information (financial measures) as a traditional method cannot be the perfect and effective way to evaluate the firm's performances (Striteska and Spickova, 2012), and it is very hard to link them with the evolution of basic "internal processes" and further goals (Zizlavsky, 2014). Since when TQM introduced its principles like customer's satisfaction, and continuous improvement, other factors could be considered to stimulate TQM implementation positively to achieve its goals over the long term into any companies. But Oakland (2003) argued that the majority of the managers have poor knowledge concerning organization's performance measures, and are often interested in financial indicators, which cannot be a comprehensive and effective tool to assess. In the $21^{\text {st }}$ century, the emphasis has moved from tangible assets to "knowledge-based strategies" founded on intangible assets, and a movement away from topdown strategic formulation (Mackay, 2005). Traditionally, the basis of quality aspect was on specified standard, but it is not implicated any more because new version TQM is emphasized on the voice of the customer as most important criterion (Oakland, 2003). Nowadays, the organization cannot rely on quantifiable performance indicators such as "cost" and "time" only, while denying qualitative performance indicators such as "customer satisfaction" and "innovation" (Hafeez et al., 2006).

The Performance measurement system (PMS) is a set of performance measures (KPIs) that has a significant role to evaluate the inputs and outputs in "manufacturing operations" or "construction activities", and acts as a strategic management tool for continuous improvements" in implementing TQM (Takim and Akintoye, 2002). PMS is a fundamental part of TQM body. Shreyas et al. (2015) stated that the main intention of TQM implementation is to establish a performance measurement framework for assessing and analyzing the performances and processes to improve project quality and the satisfaction of stakeholders in the construction projects. Sine 1980, many local, national and transnational quality awards (QAs) have been established, to provide guidelines for applying successful TQM implementation 
in practice. The most widely known of these awards are the Deming Prize in Japan, the MBNQA in the USA, and the EQA. Quality awards (QAs) have one approach for performance measurement as the main part of quality frameworks. Specially, the EFQM and MBNQA both have self-assessment system to evaluate the system for quality. TQM always encourages the firms to apply different quality measurement tools, such as statistical methods, quality costs, and benchmarking, for monitoring TQM performance with the aim of improving quality. Therefore, the philosophy of PDCA cycle that has adopted in different quality management tools, is to measure "organization's performance", and its third step is exclusive for assessment or checking performance of step one and two (Plan and Do), which were done previously (Sokovic, et al., 2010). Meanwhile, the measurement of the organization's performance is an important step when formulating the direction of the strategic activities. It is important to know where the strengths and weaknesses of the organization lie, and as part of PDCA cycle, measurement plays a key role in achieving performance excellence.

As discussed previously, MBNQA (Baldrige award) has a system to measure organization's performance, widely known "self-assessments". The principle of this award is to achieve "performance excellence" in management practices to improve organization's performance. The level of performance excellence can be indicated by measuring the performance that called self-assessment in the Baldrige award. An organization can commit to determine the level of performance if the results were with satisfactory, then the firm can apply for full scale measurement through third party Baldrige assessors (Chandra, 2013). MBNQA includes the seven categories of concepts and values in quality management with maximum total score of 1000 to evaluate how many score is the level of organization's performance regarding the world-class competition through quality management of products and services. The first six of its criteria are called "systematic processes" with $550 \mathrm{pts}$, and the seventh criterion is result category with 450 pts, which assess performance, in order to improve all activities related to quality issues in the organization. The result criterion of MBNQA is classified to five areas, which are namely: (1) "product and process outcomes" with 120 pts; (2) "customer-focused outcomes" with 90 pts.; (3) "workforcefocused outcomes" with 80 pts.; (4) "leadership and governance outcomes" with 80 pts., and; (5) "financial and market outcomes" with 80 pts. (NTSI, 2011). The second international QAs is EFQM that has also a unique measure system for its quality system with different specifications that widely known "result". The results section of the model describes, what the organization has achieved, and is currently being gotten (Mackay, 2005). EFQM framework has two parts with nine criteria, the total score of each part is the same (500 pts.). The first part is "enablers" and the second part is realm of "results" that are included: "Customer results" (200 ppt), (2) "People results" (90 ppt), (3) "Society results" (60 ppt), and (4) "Business results" (150 ppt) (EFQM, 2013).

In construction industry, some authors like Forbes and Ahmed (2011) justified because the contractors and managers are very busy to investigate and determine the critical criteria (TQM CSFs, and PMS) for developing an effective TQM framework in the construction firms. Consequently, the best way is to adopt quality awards (QAs), in order to ensue the high level of quality in construction processes. In against, Oakland (2003) stressed that formal TQM like MBNQA and EQA give only broad guidelines, and it is difficult to identify which practices and organizational results (KPIs) are derived from the use of TQM programs (especially, construction firms that do not have enough experience in implementing TQM). Also, Shiba and Walden (2006) emphasized on developing an appropriate performance measurement model for recognizing successful company efforts with "quality" and "breakthrough" in the organizations. This aim can be happened to establish an effective model with indicators that enables to evaluate the activities that happened at the past, are happening now, and to predict them for future during implementing management practices (TQM), they categorized and interpreted the performance measures as three "eyes of Buddhism", which are related to the three main types of management that top managers should be simultaneously considered with, as can be seen in Figure 1. Similarly, Parmenter (2007, p.3) stated "a set of suitable KPIs should monitor the organization's performance that are the most critical for the current and future success of the organization". 


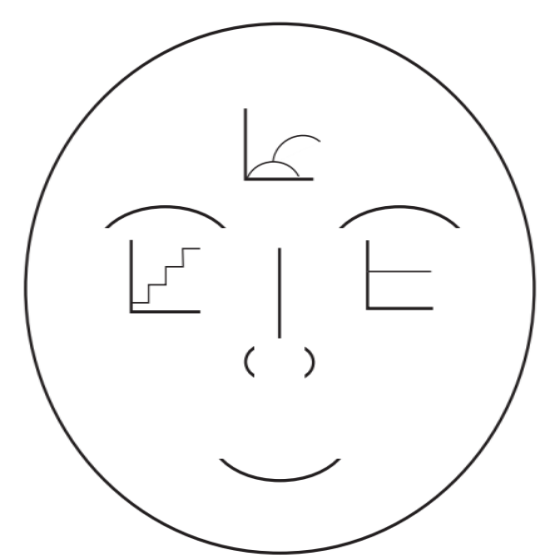

Figure 1. Eyes of the past (right), present (left), and future (top middle) (Shiba and Walden, 2006, p. 36)

The literature review reported that there are various PMSs, dimensions and KPIs have been used to measure the effects of TQM implementation on organization's performance. There is no generic performance measurement model and KPIs for TQM implementation. However, TQM framework requires identifying carefully critical things that need to be assessed in a firm, because a "well-structured performance measurement" process generates a proper linkage between objectives and real works (Pimentel and Major, 2014; Oakland, 2003). A good performance measure framework should generate the right balance, or mix of "KPIs" for TQM implementation. This aim can just be achieved by applying the layout of balanced scorecard (BSC). BSC was developed by Kaplan and Norton (1992), which is one of the most popular and practical concepts of systems, BSC enables to combine "financial and nonfinancial" indicators together by evaluating both strategic objectives and organizational performance across four interrelated perspectives: financial performance, customer perspectives, internal business processes, and innovation and growth (Oakland, 2003; Talavera, 2005; Pimentel and Major, 2014; Hafeez et al., 2006; Zizlavsky, 2014). Interestingly, BSC can be used with confidence for the performance measurement of a work in progress construction projects (Tennant and Langford, 2008, p. 365).

However, a good and effective BSC requires to specify and employ a number of indicators (KPIs) emphasizing on different dimensions of organization's performance that are the most critical for the current and future success of the firm (Oakland, 2003). Parmenter (2007) stated that a good performance measurement model based on BSC can assess the most of the core critical success factors in different dimensions, but many firms are adopted with improper PMS with wrong KPIs, and the only few firms really monitor their true KPIs based on BSC. The reason is that very few companies, business leaders, scholars, and consultants have investigated what a KPI actually is, and what PMS is the best. Kalpande et al. (2012) and Oakland (2003) suggested useful method to develop an appropriate performance measurement framework for successful TQM implementation. In this technique, the most significant KPIs should be identified through empirical studies on TQM, and then balancing the financial and nonfinancial performance indicators based on BSC system. Therefore, this study sought to overcome potential shortcomings of several former studies in this field.

\section{Methodology}

The general objective of this study is to develop and present an appropriate performance measurement model based on BSC within framework of TQM implementation for construction firms at project and enterprise levels. As recommended by Kalpande et al. (2012) and Oakland (2003), the current study was carried out an extensive literature review on TQM studies as well as BSC, in order to understand the concept of BSC and identify existing performance measures (KPIs), which used by several studies to 
investigate the effects of TQM implementation on the organizations' performance from different industries in various countries. Thus, a comprehensive search was accomplished using online databases to find the empirical studies that related with the objective of this study, published in English and referred journals in the period from 2004 to 2015. These databases were namely; Elsevier Science, Google Scholar, Emerald (MCB) Database, EBSCO, ProQuest and Anbar International Management.

In this study, the review of the literature from online databases yielded 258 studies that the majority of the studies within the literature were before 2004. So, the researcher identified the only 58 studies that published between 2004 and 2015. In next step, the content analysis was used to review and examine qualitatively/subjectively papers (58 articles), in order to specify all the relevant empirical and theoretical studies related to this topic. Accordingly, a total of 26 TQM studies found and selected for further step. Finally, the existing KPIs that extracted from literature review categorized in four groups based on perspectives of BSC. For data analysis, the study employed frequency distribution as one of the techniques of exploratory data analysis that is often used to interpret data. For each group of BSC perspectives, the KPIs were ranked and arranged from highest in top part of table to lowest frequency of occurrences respectively. This method can help this research to determine easily the most important KPIs in each dimension of BSC system.

\section{Results and Discussions}

In this research, the literature review unearthed 26 studies that were fitted and suitable for the content of the study. These research papers were accomplished in three periodical stages (the period from 2004 to 2007, 2008 to 2011, and 2012 to 2015). As presented in Table 1, the majority of empirical studies on TQM, or 16 articles with a percentage of $61.5 \%$ of the total research papers were performed by scholars between 2012 and 2015.

Table 1

Summary of the specifications of selected TQM articles in this study

\begin{tabular}{|l|l|l|l|}
\hline Year of the Publication & 2004-2007 & $\mathbf{2 0 0 8}-\mathbf{2 0 1 1}$ & $\mathbf{2 0 1 2 - 2 0 1 5}$ \\
\hline No. $(\%)$ & $4(15.4 \%)$ & $6(23.1 \%)$ & $16(61.5 \%)$ \\
\hline
\end{tabular}

However, the study conducted a comprehensive TQM literature review based on empirical studies, in order to find existing KPIs that have been used by authors and scholars, with the aim of establishing an appropriate performance measurement framework for TQM implementation in construction firms. From the literature review, it was indicated that there was a wide range of performance measures or KPIs, which used for formulating performance measurement framework within TQM frameworks by Kuo et al. (2009); Martinez-Costa et al. (2008); Kheni and Ackon (2015); Saeed and Hasan (2012); Rong-Ruey et al. (2012); Kaur and Sharma (2014); Garcia-Berna and Ramirez-Aleson (2015); Bigliardi and Galati (2014); Prajogo and Hong (2008); Hassan et al. (2013); Koc (2011); Kalpande et al. (2012); Al-Otaibi et al. (2015); Alamri et al. (2014); Talavera (2005); Irfan and Kee (2013); Prajogo and Sohal (2006); Martıinez-Costa et al. (2009); Martínez-Costa and MartínezLorente (2004); Tan et al. (2013); GarciaBerna and Ramirez-Aleson (2010); Mangula (2013); Padma et al. (2012); Bahri et al. (2012); Islam et al. (2015); Santos-Vijande and Alvarez-Gonzalez (2007). By reviewing these 26 models for TQM implementation, about 20 KPIs were highlighted as existing KPIs (performance measures), which are demonstrated in Table 2 . 
Table 2

Commonly selected KPIs by scholars from 26 TQM frameworks

\begin{tabular}{|c|c|c|}
\hline No. & KPI & Author/s \\
\hline 1 & Market share & $\begin{array}{l}\text { Bigliardi and Galati (2014); Martinez-Costa et al. (2009); Martinez-Costa et al. } \\
\text { (2008); Martínez-Costa and Martínez-Lorente (2004); Bahri et al. (2012); Islam et } \\
\text { al. (2015); GarciaBerna and Ramı'rez-Aleson (2010); Talavera (2005); Padma et } \\
\text { al. (2012). }\end{array}$ \\
\hline 2 & Quality cost & $\begin{array}{l}\text { Martinez-Costa et al. (2008); Kheni and Ackon (2015); Garcia-Berna and } \\
\text { Ramirez-Aleson (2015); Hassan et al. (2013); Kuo et al. (2009); Padma et al. } \\
\text { (2012). }\end{array}$ \\
\hline 3 & $\begin{array}{l}\text { Customer's } \\
\text { satisfaction }\end{array}$ & $\begin{array}{l}\text { Kheni and Ackon (2015); Saeed and Hasan (2012); Rong-Ruey et al. (2012); } \\
\text { Martinez-Costa et al. (2008); Kaur and Sharma (2014); Islam et al. (2015); } \\
\text { Garcia-Berna and Ramirez-Aleson (2015); Garcia-Berna and Ramirez-Aleso'n } \\
\text { (2010); Kalpande et al. (2012); Alamri et al. (2014); Irfan and Kee (2013); } \\
\text { Martinez-Costa et al. (2009); Kuo et al. (2009); Martínez-Costa and Martínez- } \\
\text { Lorente (2004); Tan et al. (2013); Padma et al. (2012); Bahri et al. (2012); } \\
\text { Talavera (2005). }\end{array}$ \\
\hline 4 & $\begin{array}{l}\text { Conformace to } \\
\text { spec.or } \\
\text { (Quality ) }\end{array}$ & $\begin{array}{l}\text { Kheni and Ackon (2015); Saeed and Hasan (2012); Bigliardi and Galati (2014); } \\
\text { Prajogo and Hong (2008); Prajogo and Sohal (2006); Kalpande et al. (2012); } \\
\text { Saeed and Hasan (2012); Alamri et al. (2014); Talavera (2005); Irfan and Ke } \\
\text { (2013); Martinez-Costa et al. (2009); Martinez-Costa et al. (2008); Kuo et al. } \\
\text { (2009); Martínez-Costa and Martínez-Lorente (2004); Tan et al. (2013); } \\
\text { Competitiveness; Mangula (2013); Bahri et al. (2012); Islam et al. (2015). }\end{array}$ \\
\hline 5 & Flexibility & $\begin{array}{l}\text { Martínez-Costa and Martínez-Lorente (2004); Martinez-Costa et al. (2008); } \\
\text { Martinez-Costa et al. (2009). }\end{array}$ \\
\hline 6 & $\mathrm{ROA}$ & $\begin{array}{l}\text { Rong-Ruey et al. (2012); Bigliardi and Galati (2014); Martínez-Costa and } \\
\text { Martínez-Lorente (2004); Islam et al. (2015). }\end{array}$ \\
\hline 7 & Profitability & $\begin{array}{l}\text { Garcia-Berna and Ramirez-Aleson (2015); Padma et al. (2012); Koc (2011); Islam } \\
\text { et al. (2015); Talavera (2005) }\end{array}$ \\
\hline 8 & ROI & Bigliardi and Galati (2014); Bahri et al. (2012). \\
\hline 9 & $\begin{array}{l}\text { Employee } \\
\text { satisfaction }\end{array}$ & $\begin{array}{l}\text { Saeed and Hasan (2012); Rong-Ruey et al. (2012); Kaur and Sharma (2014); } \\
\text { Garcia-Berna and Ramirez-Aleson (2015); Garcia-Berna and Ramirez-Aleson } \\
\text { (2010); Kalpande et al. (2012); Bahri et al. (2012); Alamri et al. (2014); Irfan and } \\
\text { Kee (2013); Martinez-Costa et al. (2009); Martinez-Costa et al. (2008); Kuo et al. } \\
\text { (2009); Martínez-Costa and Martínez-Lorente (2004); Tan et al. (2013); Padma et } \\
\text { al. (2012); Talavera (2005); Islam et al. (2015) }\end{array}$ \\
\hline 10 & ipplier & Kuo et al. (2009); Santos-Vijande and Alvarez-Gonzalez (2007). \\
\hline 11 & Time & $\begin{array}{l}\text { Kheni and Ackon (2015); Rong-Ruey et al. (2012); Garcia-Berna and Ramirez- } \\
\text { Aleson (2010); Hassan et al. (2013); Martinez-Costa et al. (2009); Martinez-Costa } \\
\text { et al. (2008); Kuo et al. (2009); Martínez-Costa and Martínez-Lorente (2004); } \\
\text { Bahri et al. (2012); Talavera (2005). }\end{array}$ \\
\hline 12 & $\begin{array}{l}\text { Costs of } \\
\text { Production }\end{array}$ & $\begin{array}{l}\text { Martinez-Costa et al. (2008); Garcia-Berna and Ramirez-Aleson (2010); Bigliardi } \\
\text { and Galati (2014); Martinez-Costa et al. (2009); Martínez-Costa and Martínez- } \\
\text { Lorente (2004); Bahri et al. (2012); Talavera (2005). }\end{array}$ \\
\hline
\end{tabular}




\begin{tabular}{|l|l|l|}
13 & Defects rate & $\begin{array}{l}\text { Kheni and Ackon (2015); Rong-Ruey et al. (2012); Hassan et al. (2013); Kuo et al. } \\
\text { (2009); Bahri et al. (2012); Talavera (2005). }\end{array}$ \\
\hline 14 & Wastage & $\begin{array}{l}\text { Garcia-Berna and Ramirez-Aleson (2010); Kheni and Ackon (2015); Islam et al. } \\
\text { (2015); Garcia-Berna and Ramirez-Aleson (2015); Bahri et al. (2012). }\end{array}$ \\
\hline 15 & $\begin{array}{l}\text { Rework / } \\
\text { Reprocessing }\end{array}$ & $\begin{array}{l}\text { Kheni and Ackon (2015); Garcia-Berna and Ramirez-Aleson (2010); Rong-Ruey } \\
\text { et al. (2012); Garcia-Berna and Ramirez-Alesón (2015); Bahri et al. (2012); } \\
\text { Talavera (2005). }\end{array}$ \\
\hline 16 & Design quality & $\begin{array}{l}\text { Martinez-Costa et al. (2009); Martinez-Costa et al. (2008); Martínez-Costa and } \\
\text { MartínezLorente (2004). }\end{array}$ \\
\hline 17 & Sales growth & $\begin{array}{l}\text { Bigliardi and Galati (2014); Padma et al. (2012); Padma et al. (2012); Islam et al. } \\
\text { (2015); Talavera (2005) }\end{array}$ \\
\hline 18 & Innovation & $\begin{array}{l}\text { Competitivene } \\
\text { Prajogo and Sohal (2006); Prajogo and Hong (2008); Bigliardi and Galati (2014). }\end{array}$ \\
\hline Padma et al. (2012); Al-Otaibi et al. (2015); Islam et al. (2015). \\
\hline 20 & Productivity & $\begin{array}{l}\text { Garcia-Berna and Ramirez-Aleson (2015); Garcia-Berna and Ramirez-Aleson } \\
\text { (2010); Bigliardi and Galati (2014); Hassan et al. (2013); Martínez-Costa and } \\
\text { Martínez-Lorente (2004); Padma et al. (2012); Bahri et al. (2012); Islam et al. } \\
\text { (2015). }\end{array}$ \\
\hline
\end{tabular}

As mentioned previously, BSC has been caused a paradigm shift in terms of organizational performance measurement, and changed the notion of the managers from "financial performance" to "multiple financial and non-financial" performance indicators. Thus, the managers have changed their considerations from "operational activity" to strategic guidance. Several scholars justified that establishing a suitable performance measurement framework can just be happened by adopting BSC (Oakland, 2003; Pimentel and Major, 2014; Mackay, 2005). Hafeez et al. (2006) stressed that TQM practices with BSC as an effective PMS provides a good metric for the companies to realize TQM efforts in terms of "financial" and "non-financial performance". Accordingly, the 20 KPIs identified through literature review, were categorized carefully, and then organized based on four perspectives of BSC, such as, customer perspective, internal business perspective, innovation and learning perspective and financial perspective, as shown in Table 3. Each of the perspectives of BSC implicates to a set of KPIs that focuses on certain performance in the organizations, as discussed below:

Internal Business Perspective: KPIs monitor the activities, which related to satisfy the customers; Innovation and Learning: KPIs measure the skills and knowledge of employees that the company should excel at to achieve superior internal business processes that create value for customers and shareholders, such as, employee education and skill level, employee satisfaction (Kaplan and Norton, 1992);

Customer Perspective: KPIs focuses on the customers' opinion on the quality of products, or services, and how company wants to be viewed by its customers (Kaplan and Norton, 1992), and;

Financial Perspective: This perspective refers to the financial view of a company as presented to its shareholders and whether the strategy, implementation and execution of the company are contributing to bottom-line improvement (Kaplan and Norton, 1992).

As shown in Table 3, each of 20 KPIs classified in four dimensions of BSC, and then KPIs of each perspective was arranged from highest to lowest frequently used by scholars. Parmenter (2007) justified "10/80/10 rule" says that it is inappropriate to develop a performance measures framework with more, or less than 10 KPIs, because many KPIs can generate difficulties to evaluate organization's performance , 
lack of focus and alignment, and underachievement. Likewise, few KPIs cannot properly indicate all critical aspects of the organization. Consequently, this study was just selected 10 KPIs from four perspectives of BSC. From Table 3, six KPIs adopted from two most widely used KPIs of three perspectives of BSC, such as, learning and growth (employees satisfaction and sale growth), financial (quality cost and profitability), and customer perspective (customer's satisfaction and market share). Finally four most frequently cited KPIs were selected as KPIs of internal business process perspective of BSC (conformance to specifications, time, productivity, and costs of production processes). The reason that this study used two more performance measures in internal business process than other three perspectives is the existence of many activities in design and construction processes. Therefore, the construction companies need to adopt sufficient KPIs for evaluating the critical factors related construction activities during implementing TQM.

Table 3

The existing KPIs from 26 TQM frameworks that arranged based on BSC system

\begin{tabular}{|c|c|c|c|c|c|}
\hline Perspective & KPI & $\begin{array}{l}\text { Frequenc } \\
\mathbf{y}\end{array}$ & Perspective & KPI & Frequency \\
\hline \multirow{7}{*}{$\begin{array}{l}\text { LEARNING } \\
\& \\
\text { GROWTH } \\
\text { (INNOVATIO } \\
\text { N) }\end{array}$} & $\begin{array}{l}\text { Employee's } \\
\text { satisfaction }\end{array}$ & 17 & \multirow{7}{*}{$\begin{array}{l}\text { INTERNAL } \\
\text { BUSINESS } \\
\text { PROCESSES }\end{array}$} & $\begin{array}{l}\text { Conformance to } \\
\text { specifications } \\
\text { (Quality) }\end{array}$ & 18 \\
\hline & Sales growth & 4 & & $\begin{array}{l}\text { Time } \\
\text { Productivity }\end{array}$ & $\begin{array}{l}10 \\
8\end{array}$ \\
\hline & \multirow{2}{*}{$\begin{array}{l}\text { Product and process } \\
\text { innovation }\end{array}$} & \multirow{2}{*}{3} & & Costs of processes & 7 \\
\hline & & & & Defects rate & 6 \\
\hline & \multirow{2}{*}{ Flexibility } & \multirow{2}{*}{3} & & Design quality & 6 \\
\hline & & & & Wastage & 5 \\
\hline & Competitiveness & 3 & & $\begin{array}{l}\text { Rework/Reprocessin } \\
\mathrm{g}\end{array}$ & 5 \\
\hline \multirow{4}{*}{ FINANCIAL } & Quality cost & 6 & \multirow{4}{*}{ CUSTOMER } & \multirow{2}{*}{$\begin{array}{l}\text { Customer's } \\
\text { satisfaction }\end{array}$} & \multirow{2}{*}{18} \\
\hline & Profitability & 5 & & & \\
\hline & ROA & 4 & & Market share & 9 \\
\hline & ROI & 2 & & $\begin{array}{l}\text { Supplier } \\
\text { performance }\end{array}$ & 2 \\
\hline
\end{tabular}

\section{Conclusions}

As mentioned earlier, the main purpose of this study was to develop an appropriate performance measurement framework for TQM implementation in construction industry. Oakland (2003), and Kalpande et al. (2012) asserted the practitioners and scholars should review TQM empirical studies in different sectors with the aim of specifying most significant performance measures (KPIs) to evaluate the performance of TQM implementation on critical elements in different areas of the organization. Thus, the study examined 26 TQM models that extracted from main databases, these frameworks were developed for measuring the effects of TQM and its elements on the organization's performance by authors in different industries and countries. In data analysis, the 20 KPIs identified that were derived from 26 TQM frameworks. 
Parmenter (2007) stated the successful development and utilization of key performance indicators (KPIs) in the workplace can be generated by balancing performance measures in four foundation stones of BSC Consequently, the extracted KPIs of previous empirical studies on TQM implementation (20 KPIs) classified in four perspectives, and ten most frequently used KPIs were finally selected of these perspectives of BSC, which includes more than just measuring, but also defining and understanding metrics, collecting and analyzing data, and prioritizing and taking improvement actions. Interestingly, the performance measurement framework outlined in this study is an excellent management tool as recommended by Shiba and Walden (2006). This framework possesses proper financial and non-financial performance measures, which are able to indicate the activities happened at the past, are happening now, and likewise to predict them for future in the construction firms at project and enterprise levels. The measure indicators of internal business process (conformance to specifications (quality), time, productivity, and costs of processes) and financial indicators (quality cost and profitability) can indicate the level of performance of company at past. The KPIs of customer (customer's satisfaction and market share) can show the condition of company now. Likewise, the performance indicators of learn and growth measures (employee's satisfaction and sale growth) can be able to predict the future of construction company based on the results of measuring this dimension of BSC.

Furthermore, this study proposed the following model to assess the performance of TQM implementation for further studies in construction, or even other industry as well. Also, the practitioners can link TQM practices, or quality tools to this framework, in order to understand whether the benefits of TQM implementation, or other quality management programs being achieved by the organizations as a proper organizational performance framework, as presented in the Figure 2.

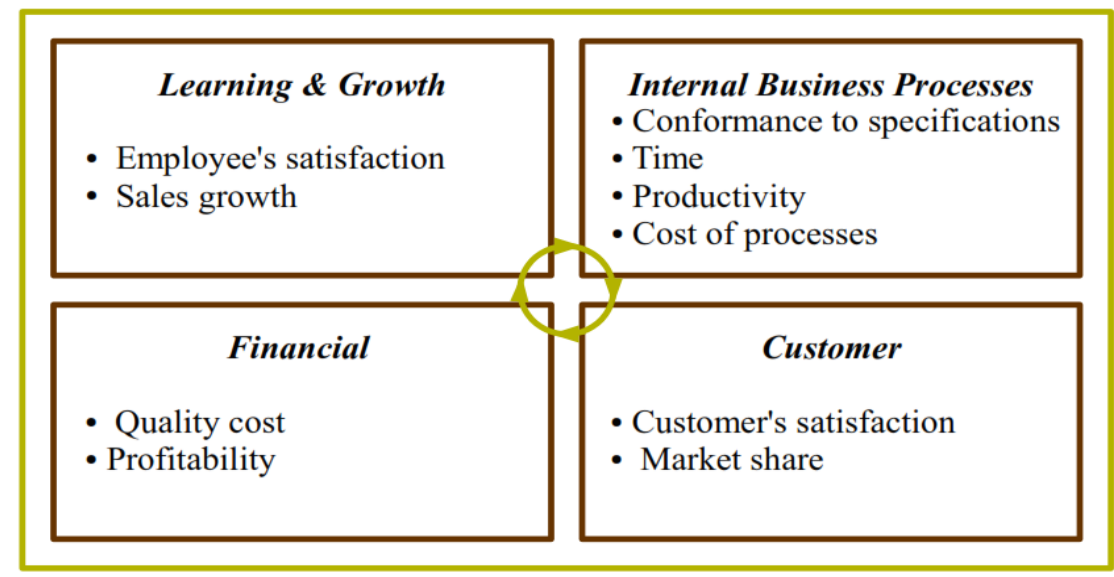

Figure 2. An appropriate performance measurement framework for TQM implementation

\section{References}

Alamri, A.M., Alharthi, A.M., Alharthi, D.K., Alhabashi, W.S., \& Hasan, S.A. (2014). Organization, Performance Improvement using TQM, International Journal of Computer Applications, 108(9), pp.,29-33.

Al-Otaibi, F.M., Alharbi, M.F., \& Almeleehan, A. (2015). Effect of Total Quality Management Practices Factors on the Competitiveness: Evidence from Saudi Arabia, International Journal of Business and Management, 10(5), pp. 85-97.

Bahri, S., Hamzah, D., \& Yusuf, R.M. (2012). Implementation of Total Quality Management and Its Effect on Organizational Performance of Manufacturing Industries Through Organizational Culture in South Sulawesi, Indonesia, IOSR Journal of Business and Management, 5(1), pp. 10-24. 
Bigliardi, B., \& Galati, F. (2014). The Implementation of TQM in R\&D Environments, Journal of Technology Management \& Innovation, 9(2), pp. 157-171.

Burli, S.B., Kotturshettar, B.B., \& Dalmia, R.V. (2012). Multiple Performance Measures: Six TQM Practices, SCMS Journal of Indian Management, January - March, 2012, pp. 69-79.

Chandra, P.V. (2013). A Study on Implementation of Total Quality Management in Businesses, International Journal of Engineering Science and Innovative Technology, 2(3), pp. 440-446.

EFQM (2013). An overview of The EFQM Excellence Model. Retrieved from http://www.efqm.org/sites/default/files/overview_efqm_2013_v1.pdf. (Accessed in 2015, Dec. 5).

Forbes, L H. \& Ahmed S. M. (2011). Modern construction : lean project delivery and integrated practices. Boca Raton, Fly: Taylor and Francis Group.

Garcia-Berna, J., \& Ramirez-Aleson M. (2010). Increasing the organizational performance benefits of TQM: an approach based on organizational design, Total Quality Management Journal, 21(4), pp. 363-382.

Garcia-Berna, J., \& Ramirez-Aleson M. (2015). Why and How TQM Leads to Performance Improvements, Quality Management Journal (ASQ), 22(3). pp. 23-37.

Hafeez, K., Malak, N., \& Abdelmeguid, H. (2006). A Framework for TQM to Achieve Business Excellence, Journal of Total Quality Management \& Business Excellence, 17(9), pp. 1213-1229.

Harrington, H.J., Voehl, F., \& Wiggin, H. (2012). Applying TQM to the construction industry. The TQM Journal, 24(4), pp. $352-362$.

Hassan, M., Hassan, S., Shaukat, S., \& Nawaz, M.S. (2013). Relationship between TQM Elements and Organizational Performance: An Empirical Study of Manufacturing Sector of Pakistan, Pakistan Journal of Commerce and Social Sciences, 7 (1), pp. 01-18.

Irfan, S.M., \& Kee, D.H. (2013). Critical Success Factors of TQM and its Impact on Increased Service Quality: A Case from Service Sector of Pakistan, Middle-East Journal of Scientific Research, 15(1): pp. 61-74.

Islam, M.M., Karim, M.A., \& Habes, E.M. (2015). Relationship Between Quality Certification and Financial \& Non- Financial Performance of Organizations, Journal of Developing Areas, 49(6), pp. 119-132.

Kaplan, R. S., \& Norton, D. P. (1992). The Balanced Scorecard - Measure That Drive Performance. Harvard Business Review, 70(1), pp. 71-79.

Kuo, T., Chang, T., Hung, K., \& Lin, M. (2009). Employees' perspective on the effectiveness of ISO 9000 certification: A Total Quality Management framework, Journal of Total Quality Management \& Business Excellence, 20(12), pp. 1321-1335.

Kheni, N.A., \& Ackon, F. (2015). Impact of Total Quality Management Practices (TQMPs) on Construction Project Quality Performance in Developing Countries: Study of Construction Businesses in Ghana, International Journal of Management Science, 2(3), pp. 35-51.

Kaur, P., \& Sharma, S.K. (2014). Evaluating the Relationship and Influence of Critical Success Factors of TQM on Business Performance: Evidence from SMEs of Manufacturing Sector, IUP Journal of Operations Management, 13(4), pp. 17-30.

Koc, T. (2011). The Relationship Between TQM and Performance in Small Manufacturing Enterprises: The Mediation Effect of Failure, International Journal of Industrial Engineering, 18(4), pp. 203218.

Kalpande, S. D., Gupta, R .C., \& Dandekar, M. D. (2012). FRAMEWORK OF TQM IMPLEMENTATION IN SMALL BUSINESSES OF AN INDUSTRIALLY BACKWARD REGION: A CONCEPT, Journal of International Society for Performance Improvement, 51(7), pp. 7-13.

Lee, D.E., Lim, T.K., \& Arditi, D. (2011). An Expert System for Auditing Quality Management Systems in Construction. Computer-Aided Civil and Infrastructure Engineering 26 (2011), pp. 612-631.

Mackey, A \& Gass, S.M. (2005). Second language research : methodology and design. Mahwah, NJ: Lawrence Erlbaum Associates, Inc. 
Mangula, M.S. (2013). Effect Of Quality Management Systems Certification On Organizational Performance In Tanzania: A Case Of Manufacturing Industries In Morogoro, International Journal of Technology Enhancements and EMERGING Engineering Research, 1(1). pp. 14-19.

Martinez-Costa, M., Martinez-Lorente, A.R. \& Choi, T. Y.,(2008). Simultaneous consideration of TQM and ISO 9000 on performance and motivation: An empirical study of Spanish companies, International Journal of Production Economics, 113 (2008), pp. 23-39.

Martinez-Costa, M., Choi, T. Y., Martinez, J. A., \& Martinez-Lorente, A.R. (2009). ISO 9000/1994, ISO 9001/2000 and TQM: The performance debate revisited, Journal of Operations Management, 27 (2009), pp. 495-511.

Mehmood, S., Qadee, F., \& Ahmad, A. (2014). Relationship between TQM Dimensions and Organizational Performance, Pakistan Journal of Commerce and Social Sciences, 8 (3), pp. 662679.

NTSI (2011). 2011-2012 Criteria for Performance Excellence. Retrieved from http://www.nist.gov/baldrige/publications/upload/2011_2012_Business_Nonprofit_Criteria.pdf (Accessed in 2015, December 5).

Oakland, J. S. (2003). Total Quality Management: text with cases ( $3^{\text {rd }}$ ed.). Jordan Hill, Oxford, UK: Butterworth-Heinemann, an imprint of Elsevier.

Omachonu, V. K. \& Ross, J. E. (2004). Principles of total quality ( $3^{\text {rd }}$ ed.). Boca Raton, Florida: Taylor \& Francis.

Padma, P., Ganesh L. S., \& Rajendran, C. (2012). A study on the critical factors of ISO 9001:2000 and organizational performance of Indian manufacturing firms, International Journal of Production Research, 2006, pp. 1-31.

Parmenter, D. (2007). Key performance indicators: developing, implementing, and using winning KPIs. Hoboken, New Jersey: John Wiley \& Sons, Inc.

Pimentel, L., \& Major, M.J. (2014). Quality management and a balanced scorecard as supporting frameworks for a new management model and organizational change, Journal of Total Quality Management \& Business Excellence, 25(7), pp. $763-775$.

Prajogo, D.I., \& Sohal, A.S. (2006). The relationship between organization strategy, total quality management (TQM), and organization performance-the mediating role of TQM, Journal of European Journal of Operational Research ,168 (2006), pp. 35-50

Prajogo, D.I., \& Hong, S.W. (2008). The effect of TQM on performance in R\&D environments: A perspective from South Korean firms, Journal of Technovation, 28 (2008), pp. 855-863.

Rong-Ruey D., Audrey W.H., \& Pei-Wen H. (2012). Determinants and performance effect of TQM practices: An integrated model approach, Total Quality Management Journal, 23(6), pp. 689-701.

Saeed, N.M. , \& Hasan, A.S. (2012). The Effects of Total Quality Management on Construction Project Performance: Case Study: Construction Firms in Yemen, Journal of Science \& Technology, 17(2), pp. 11-30.

Santos-Vijande, M.L., \& Alvarez-Gonzalez, L.I. (2007). TQM and firms performance: An EFQM excellence model research based survey, International Journal of Business Science and Applied Management, 2(2), pp. 21-41.

Shiba, S., \& Walden, D. (2006). BREAKTHROUGH MANAGEMENT PRINCIPLES, SKILLS, AND MODELS FOR TRANSFORMATIONAL LEADERSHIP, Retrieved from http://www.cqm.org/breakthrough, (Accessed in 2015, Sep. 11).

Shreyas, G., Ramesh, N., Sachidananda, M.S., \& Shashi, K.B. (2015). Total Quality Management in Construction, International Research Journal of Engineering and Technology, 2(5), pp. 12431247.

Sokovic, M., Pavletic D., \& Pipan, K.K. (2010). Quality Improvement Methodologies - PDCA Cycle,RADAR Matrix, DMAIC and DFSS, Journal of Achievements in Materials and Manufacturing Engineering, 43(1), pp. 476- 483.

Striteska, M., \& Spickova, M. (2012). Review and Comparison of Performance Measurement Systems, Journal of Organizational Management Studies, 2012 (11), pp. 1-13. 
Talavera, G.V. (2005). TQM Adoption and Firm Performance in the Philippines, Philippine Management Review, 2005(12), pp. 23-44.

Takim, R. \& Akintoye, A. (2002) Performance indicators for successful construction project performance. In: Greenwood, D (Ed.), $18^{\text {th }}$ Annual ARCOM Conference, 2-4 Sept., 2002(2), pp. 545-55.

Tan, B.I., Wong, K.L., \& Choong, C.K. (2013). TQM and Family Owned Business: Performance and Sustainability, Proceedings of of 2013 International Conference on Technology Innovation and Industrial Management, 29-31 May 2013, Phuket, Thailand.

Tang, W., Qiang M., Duffield C.F., Young D.M., \& Lu, Y. (2009). Enhancing Total Quality Management by Partnering in Construction. Journal of Professional Issues in Engineering Education and Practice, 135(4), PP. -129-141.

Tennant, S., \& Langford, D. (2008). The construction project balanced scorecard. In: Dainty, A (Ed), Proceedings of 24 ${ }^{\text {th }}$ Annual ARCOM Conference, pp. 361-370, 1-3 Sep. 2008, Cardiff, UK.

Zizlavsky, O. (2014). The Balanced Scorecard: Innovative Performance Measurement and Management Control System, Journal of Tech. Management \& Innovation, 9(3), pp. 210-222. 